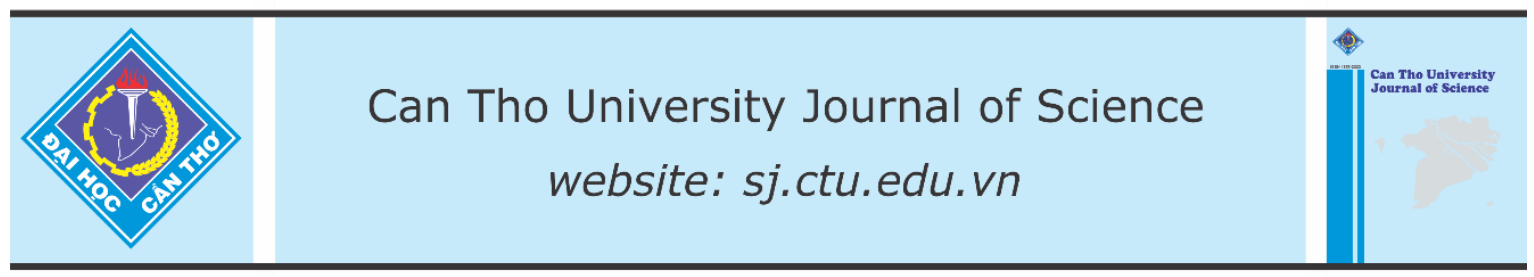

DOI: 10.22144/ctu.jen.2020.020

\title{
Teachers' motivation and its influence on quality education: A study at a center for foreign languages in Vietnam
}

\author{
Luu Nguyen Quoc Hung* \\ Center for Foreign Languages, Can Tho University, Vietnam \\ *Correspondence: Luu Nguyen Quoc Hung (email: Inqhung@ctu.edu.vn)
}

\section{Article info.}

Received 19 Apr 2020

Revised 09 Jun 2020

Accepted 30 Nov 2020

\section{Keywords}

Motivation, performance, quality education, teachers

\begin{abstract}
Teacher is one of the most important elements in education. The quality of education is largely determined by the teacher's quality. Few would argue against the view that motivated staff are a central resource for the success and quality of an organization, and thus attention needs to be given to examining teachers' motivation as a key to guaranteed quality education. At the Center for Foreign Languages, Can Tho University, teachers are always recognized as key factors for the success of the institution. This smallscale study was conducted with 42 teachers of English of the Center for Foreign Languages with the aim to examine common factors affecting teachers' motivation and their perceptions towards quality education. The results of the survey revealed the most common factors for teachers' motivation and the findings from focus group discussions indicated the positive relationship of teachers' level of motivation with quality education.
\end{abstract}

Cited as: Hung, L.N.Q, 2020. Teachers' motivation and its influence on quality education: A study at a center for foreign languages in Vietnam. Can Tho University Journal of Science. 12(3): 17-26.

\section{INTRODUCTION}

In this incredibly challenging and complex world, quality education is the solution to all the problems, and teachers are the main ingredients in giving quality education (Agatha, 2015). The issue of teachers' motivation and quality education has become a matter of debate and concern in educational systems and standards. It is acknowledged that any nation that is aspiring to maintain high quality standards in its educational system must take teachers and their motivational needs with utmost high level of seriousness (Ofojebe and Ezugoh, 2010). World Bank (1994) emphasized that high quality and well-motivated teaching staff are essential for any institution to enhance its excellence. Improving the teachers' moti- vation generally improves teaching, and thus, raising the motivation of teachers as well as retaining high-quality teachers is therefore vital to improving quality education.

Teachers' motivation generally determines their level of involvement in the teaching activities. It is believed that a motivated teacher will work harder, try new techniques and activities, and in general do more for the sake of the learners (Gokce, 2010). As a teacher, it is not just important but rather imperative to be both intrinsically and extrinsically motivated and satisfied in order to maintain the motivation to teach over the course of one's career.

Teachers' motivation is influenced by a myriad of factors, including compensation, success in the classroom, their dedication to the profession, the 
training they receive and the prospect of promotion and career advancement (Sah, 2016). A study of examining influence of motivational factors on teachers is, therefore, important as motivation is the driving force behind all actions the teachers take at workplace. While most studies on teacher motivation have been centered in university settings, it appears that few studies have been done on teacher motivation in the context of foreign languages centers, especially in Vietnamese context. The main objective of this study is to examine the importance of teachers' motivation and its influence on quality education among the English language teachers in a foreign languages center in Can Tho City, Vietnam.

\section{LITERATURE REVIEW}

\subsection{Motivation and motivational theories}

Motivation may mean different things to different people as people can be motivated by various ways. Velez (2007) conceptualizes motivation as an inspiration or encouragement of a person to do his or her best. In educational context, Snowman et al. (2008) define motivation as the forces that lead to the arousal, selection, direction, and continuation of behavior. Bennell and Akyeampong (2007) interpreted teachers' motivation for work as a mental boost in the teachers to do their job. In a similar vein, according to Claeys (2011, p.4), teachers' motivation is the "internal desires for personal and professional development and working in educational settings".

\subsubsection{Maslow's Theory (Theory of Hierarchy of Needs)}

From humanistic theories standpoint, one of the most influential researchers in the area of motivation is Abraham Maslow. According to Maslow (1970, cited in Abdulrahman and Hui, 2018), human needs fall into a hierarchy from the most basic psychological needs to needs for self-actualization (Figure 1). His theory of hierarchy of needs proposes that individuals must fulfill their lower-order needs (basic needs such as water and housing, safety, belonging, and esteem) before being motivated to fulfill the higher-order need for self-actualization. The most important point of Maslow's hierarchy of needs is that the motivational strength of an unfulfilled higher-level need depends on the fulfillment of a lower-level need. In the context of teaching, self-actualization can be understood as personal achievement, a key component of teacher motivation.

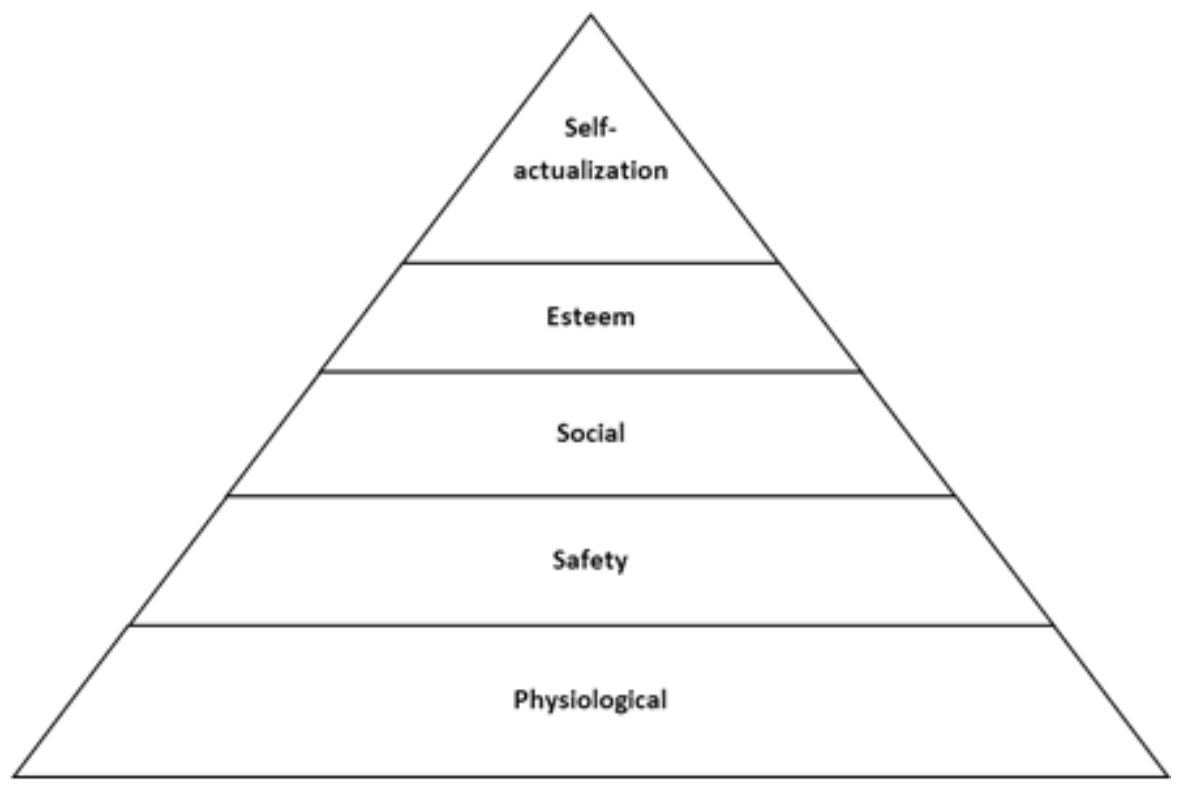

Figure 1: Maslow's hierarchy of needs

Source: Maslow's need for hierarchy (1953, cited in Rowley, 1996)

In the context of the foreign language center, the five factors of Maslow's needs for hierarchy can have some practical implications for teachers' motivation.
Physiological needs are basic biological needs which generally include food, clothing, shelter, etc. As psychological needs serve as a fundamental aspect, the center should provide a reasonable salary 
and better working condition so that the teachers can afford their basic needs such as food, clothes, and housing, so that the teachers can work in the good environment and be satisfied with their workplace which may increase the efficiency of work.

With safety needs, every teacher needs protection against any kind of danger, accidents, etc. The center can provide job security to its teachers and make them feel safe from any kind of risk. Regular work contract and work insurance may also be among the factors which increase work performance.

As for social needs, the center can enhance the relationships between the administration and teachers as well as among teachers together. A teachers' community can provide useful opportunities for teachers to participate in both professional and social activities.

As for esteem needs, teachers need appreciation at workplace, mostly recognition and focus on self-respect and respect from others. The center can give or establish a kind of award, promotion or job recognition to its teachers in order to motivate them.
With self-actualization needs, self-cultivation can be personalized differently in different people. The center should provide its teachers with opportunities for self-growth or personal development.

\subsubsection{Herzbergs' Two Factors Theory (Motivation-Hygiene Theory)}

This theory was developed by Herzberg (1959, cited in Abdulrahman and Hui, 2018) from existing theory of Maslow's Need for Hierarchy. In his theory, Herzberg proposed that there are two factors, factors for satisfaction (motivators/satisfiers) and factors for dissatisfaction (hygiene/dissatisfiers) that an organization can adjust to influence motivation in the workplace. Satisfiers or motivators are closely related to self-actualization needs, including the work itself, recognition, advancement and responsibility. Motivators are intrinsic factors directly related to the job and largely internal to the individual. Dissatisfiers or hygiene factors related to Maslow's lower needs. These include institution's policy and administration, salary, working conditions and interpersonal relations. Hygiene is about extrinsic factors. These two types of factors are presented in Table 1.

Table 1: Motivation and Hygiene Factors Theory

\begin{tabular}{ll}
\hline Motivation (Intrinsic) factors & Hygiene (Extrinsic) factors \\
\hline - Achievement & - Center's policies and administration \\
- Recognition & - Supervision \\
- Work itself & - Relationship with supervisor \\
- Responsibility & - Work condition \\
- Advancement & - Salary \\
- Growth & - Relationship with peers \\
& - Personal life \\
& - Relationship with subordinates \\
& - Status \\
& - Security \\
\hline
\end{tabular}

Source: Lunenburg and Ornstein (2010, cited in Abdulrahman and Hui, 2018)

Teachers generally have both intrinsic and extrinsic needs. A teacher who is intrinsically motivated may be observed to undertake a task for its own sake, for the satisfaction it provides or for the feeling of accomplishment and self-actualization. On the other hand, an extrinsically motivated teacher may perform the activity in order to obtain some reward such as salary. The aim of the institution should be to build on and enhance the intrinsic motivation for

Maslow's theory of hierarchy of needs teachers to teach effectively and at the same time, to supply some extrinsic motivation along the way for school improvement.

By looking from the context of the foreign language center, these theories are relevant in order to examine factors of teachers' motivation. The relationships between the two theories are presented in Figure 2 (Gokce, 2010).

\section{Herzberg's two factor theory}




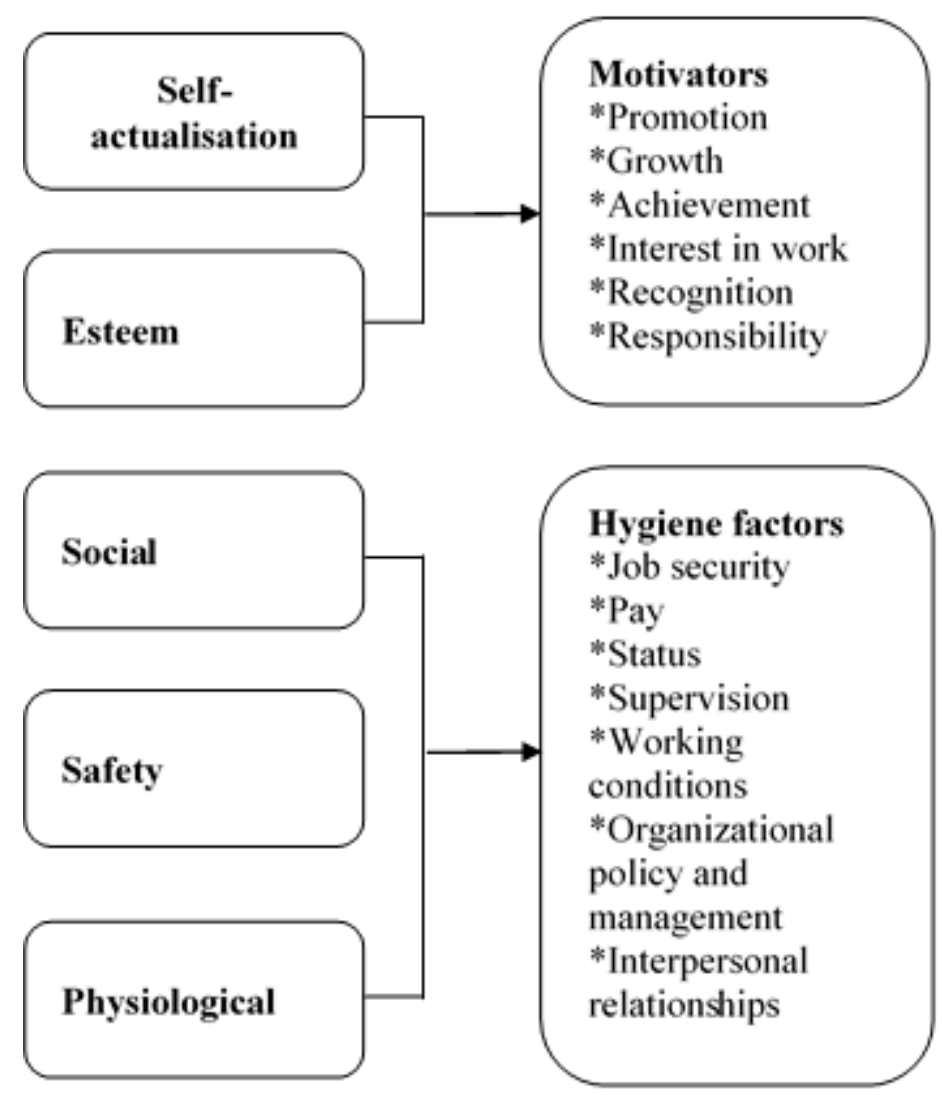

Figure 2: The relationships between the theories of motivation

\subsection{Teachers' motivation and its impact on quality education}

The concept of quality has received much attention in educational contexts in recent years (Komorowska, 2017). Quality education is the basic requirement of every nation and the people. It not only helps people to improve their skills but also enable them to work for the enhancement of the society. Quality education has been described as the success with which an institution provides educational environments which enable students effectively to achieve worthwhile learning goals including appropriate academic standards (Gordon and Partington, 1993 cited in Rowley, 1996).

Motivation of teachers is the key in the establishment and further development of quality in education. Teachers' motivation is a way of stimulating teachers in their professional job for better performance. When teachers are highly motivated and adequate attention given to them, it adds value to the education quality by raising the quality of teachinglearning process (Ayeni, 2015). The motivational process involves strategies and activities that are used by the management for the purpose of providing a climate that is conductive to the satisfaction of the various needs of the teachers so that they may become satisfied, dedicated and effective in performing their tasks. This will invariably enhance the quality of education (Orupabo and Nwankwoala, 2018).

\section{THE STUDY}

\subsection{Research methodology}

In this study, a mixed design with the descriptive survey and interviews was employed. The survey method is appropriate as it entails the development of a questionnaire based on intrinsic and extrinsic motivational elements emerging from the literature review.

\subsection{The questionnaire}

The questionnaire used to gather data for this study was adapted from the Teacher Motivation and Job Satisfaction Survey by Mertler (2001). The respondents are asked to indicate their level of motivation to 17 motivational factors, using a five-point Likert scale of Poorly motivated $=1$, Slightly motivated $=$ 
2 , Neutral $=3$, Motivated $=4$ and Strongly motivated $=5$.

\subsection{The interview}

The focus group discussions were used to obtain information on participants' perceptions towards teachers' motivation and its influence on quality education. Each focus group interview lasted 30 minutes. The interview questions helped to raise teachers' awareness of factors influencing their motivation. Following the survey, further discussions were important for detailed describing and deep understanding of teachers' motivation for quality education.

\subsection{Participants}

The surveys were handed out to teachers in a particular foreign languages center, and there were 42 respondents completing the survey. In this study, most teachers are young in their career and they are within the age range of 25 to 50 years. For the interview, four focus group discussions of five teacher participants in each were organized. Simple random sampling technique was used to select about 50 percent of participants for the interview. Names of all the participants were written on pieces of paper and put in a box. Then, 20 pieces of paper with names were randomly selected to obtain the participants for the interview.

\section{RESULTS AND DISCUSSIONS}

\subsection{Survey}

The evidence of the data analysis presented in Table 1 showed that teacher motivation was relatively high with average value of 4.20 . The comparison of mean values of 17 motivational factors and their ranking are presented, where responsibility is with the highest value and personal life scores the smallest value.

Table 1: Teacher motivation based on motivational factors

\begin{tabular}{|c|c|c|c|c|c|c|c|}
\hline \multirow{2}{*}{ Factors } & \multicolumn{5}{|c|}{ Level of motivation } & \multirow{2}{*}{ Mean } & \multirow{2}{*}{$\begin{array}{c}\text { Rank- } \\
\text { ing }\end{array}$} \\
\hline & 1 & 2 & 3 & 4 & 5 & & \\
\hline $\begin{array}{l}\text { Responsibility (e.g., au- } \\
\text { tonomy, authority and re- } \\
\text { sponsibility for own } \\
\text { work) }\end{array}$ & & & $\begin{array}{c}4 \\
(9.5 \%)\end{array}$ & $\begin{array}{c}12 \\
(28.6 \%)\end{array}$ & $\begin{array}{c}26 \\
(61.9 \%)\end{array}$ & 4.52 & 1 \\
\hline $\begin{array}{l}\text { - Salary (e.g., financial } \\
\text { compensation) }\end{array}$ & & & $\begin{array}{c}2 \\
(4.8 \%) \\
\end{array}$ & $\begin{array}{c}19 \\
(45.2 \%)\end{array}$ & $\begin{array}{c}21 \\
(50 \%)\end{array}$ & 4.45 & 2 \\
\hline $\begin{array}{l}\text { - Sense of achievement } \\
\text { (e.g., experiencing suc- } \\
\text { cess) }\end{array}$ & & & $\begin{array}{c}2 \\
(4.8 \%)\end{array}$ & $\begin{array}{c}20 \\
(47.6 \%)\end{array}$ & $\begin{array}{c}20 \\
(47.6 \%)\end{array}$ & 4.43 & 3 \\
\hline $\begin{array}{l}\text { Potential for professional } \\
\text { growth (e.g., possibility } \\
\text { of improving one's own } \\
\text { professional skills) }\end{array}$ & & & $\begin{array}{c}1 \\
(2.4 \%)\end{array}$ & $\begin{array}{c}23 \\
(54.8 \%)\end{array}$ & $\begin{array}{c}18 \\
(42.8 \%)\end{array}$ & 4.41 & 4 \\
\hline $\begin{array}{l}\text { - Job security and stability } \\
\text { (e.g., tenure) }\end{array}$ & & $\begin{array}{c}1 \\
(2.4 \%)\end{array}$ & $\begin{array}{c}4 \\
(9.5 \%)\end{array}$ & $\begin{array}{c}15 \\
(35.7 \%)\end{array}$ & $\begin{array}{c}22 \\
(52.4 \%)\end{array}$ & 4.38 & 5 \\
\hline $\begin{array}{l}\text { Working condition (e.g., } \\
\text { building conditions, } \\
\text { among of work, facilities } \\
\text { available) }\end{array}$ & & $\begin{array}{c}2 \\
(4.8 \%)\end{array}$ & $\begin{array}{c}2 \\
(4.8 \%)\end{array}$ & $\begin{array}{c}19 \\
(45.2 \%)\end{array}$ & $\begin{array}{c}19 \\
(45.2 \%)\end{array}$ & 4.31 & 6 \\
\hline $\begin{array}{l}\text { Interpersonal relation- } \\
\text { ships with students (e.g., } \\
\text { interaction with students) }\end{array}$ & $\begin{array}{c}1 \\
(2.4 \%)\end{array}$ & & $\begin{array}{c}3 \\
(7.1 \%)\end{array}$ & $\begin{array}{c}22 \\
(52.4 \%)\end{array}$ & $\begin{array}{c}16 \\
(38.1 \%)\end{array}$ & 4.24 & 7 \\
\hline $\begin{array}{ll}\text { - } & \text { Status (e.g., professional } \\
\text { status of teaching) }\end{array}$ & & & $\begin{array}{c}6 \\
(14.3 \%)\end{array}$ & $\begin{array}{c}21 \\
(50 \%)\end{array}$ & $\begin{array}{c}15 \\
(35.7 \%)\end{array}$ & 4.21 & 8 \\
\hline
\end{tabular}




\begin{tabular}{|c|c|c|c|c|c|c|c|}
\hline \multirow{2}{*}{ Factors } & \multicolumn{5}{|c|}{ Level of motivation } & \multirow{2}{*}{ Mean } & \multirow{2}{*}{$\begin{array}{c}\text { Rank- } \\
\text { ing }\end{array}$} \\
\hline & 1 & 2 & 3 & 4 & 5 & & \\
\hline $\begin{array}{l}\text { Recognition (e.g., receiv- } \\
\text { ing praise from adminis- } \\
\text { trators, parents, students, } \\
\text { or others) }\end{array}$ & & & $\begin{array}{c}7 \\
(16.7 \%)\end{array}$ & $\begin{array}{c}21 \\
(50 \%)\end{array}$ & $\begin{array}{c}14 \\
(33.3 \%)\end{array}$ & 4.17 & 9 \\
\hline $\begin{array}{l}\text { Potential for advancement } \\
\text { (e.g., possibility of as- } \\
\text { suming different positions } \\
\text { in the profession) }\end{array}$ & & & $\begin{array}{c}6 \\
(14.3 \%)\end{array}$ & $\begin{array}{c}25 \\
(59.5 \%)\end{array}$ & $\begin{array}{c}11 \\
(26.2 \%)\end{array}$ & 4.12 & 10 \\
\hline $\begin{array}{l}\text { Interpersonal relation- } \\
\text { ships with administrators } \\
\text { (e.g., interaction with ad- } \\
\text { ministrators) } \\
\end{array}$ & & & $\begin{array}{c}8 \\
(19 \%)\end{array}$ & $\begin{array}{c}22 \\
(52.4 \%)\end{array}$ & $\begin{array}{c}12 \\
(28.6 \%)\end{array}$ & 4.10 & 11 \\
\hline $\begin{array}{l}\text { - The Center's policies } \\
\text { (e.g., overall effects of the } \\
\text { Center's policies) }\end{array}$ & & $\begin{array}{c}1 \\
(2.4 \%)\end{array}$ & $\begin{array}{c}6 \\
(14.3 \%)\end{array}$ & $\begin{array}{c}24 \\
(57.1 \%)\end{array}$ & $\begin{array}{c}11 \\
(26.2 \%)\end{array}$ & 4.07 & 12 \\
\hline $\begin{array}{l}\text { Work itself (e.g., aspects } \\
\text { associated with the tasks } \\
\text { of teaching) }\end{array}$ & $\begin{array}{c}1 \\
(2.4 \%)\end{array}$ & $\begin{array}{c}1 \\
(2.4 \%)\end{array}$ & $\begin{array}{c}3 \\
(7.1 \%)\end{array}$ & $\begin{array}{c}27 \\
(64.3 \%)\end{array}$ & $\begin{array}{c}10 \\
(23.8 \%)\end{array}$ & 4.05 & 13 \\
\hline $\begin{array}{l}\text { Interpersonal relation- } \\
\text { ships with colleagues } \\
\text { (e.g., interaction with } \\
\text { other teachers) } \\
\end{array}$ & & $\begin{array}{c}3 \\
(7.1 \%)\end{array}$ & $\begin{array}{c}6 \\
(14.3 \%)\end{array}$ & $\begin{array}{c}20 \\
(47.6 \%)\end{array}$ & $\begin{array}{c}13 \\
(31 \%)\end{array}$ & 4.02 & 14 \\
\hline $\begin{array}{l}\text { Teacher evaluation (e.g., } \\
\text { appraisal of classroom in- } \\
\text { struction by evaluator) }\end{array}$ & $\begin{array}{c}1 \\
(2.4 \%)\end{array}$ & $\begin{array}{c}3 \\
(7.1 \%)\end{array}$ & $\begin{array}{c}3 \\
(7.1 \%)\end{array}$ & $\begin{array}{c}23 \\
(54.8 \%)\end{array}$ & $\begin{array}{c}12 \\
(28.6 \%)\end{array}$ & 4.00 & 15 \\
\hline $\begin{array}{l}\text { Supervision by supervi- } \\
\text { sors (e.g., overall compe- } \\
\text { tence of superiors) }\end{array}$ & $\begin{array}{c}1 \\
(2.4 \%)\end{array}$ & $\begin{array}{c}2 \\
(4.8 \%)\end{array}$ & $\begin{array}{c}3 \\
(7.1 \%)\end{array}$ & $\begin{array}{c}28 \\
(66.7 \%)\end{array}$ & $\begin{array}{c}8 \\
(19 \%)\end{array}$ & 3.95 & 16 \\
\hline $\begin{array}{l}\text { Factors in personal life } \\
\text { (e.g., effects of teaching } \\
\text { on one's personal life) }\end{array}$ & $\begin{array}{c}2 \\
(4.8 \%)\end{array}$ & $\begin{array}{c}2 \\
(4.8 \%)\end{array}$ & $\begin{array}{c}8 \\
(19 \%)\end{array}$ & $\begin{array}{c}16 \\
(38.1 \%)\end{array}$ & $\begin{array}{c}14 \\
(33.3 \%)\end{array}$ & 3.91 & 17 \\
\hline & & & & Mean & average & 4.20 & \\
\hline
\end{tabular}

The five main motivators for teachers were both intrinsic and extrinsic, including "responsibility", "salary", "sense of achievement", "potential for professional growth" and "job security and stability". The most important reason found to be intrinsically motivating for teachers was 'responsibility' (e.g., autonomy, authority and responsibility for own work). Based on the percentage of response, approximately $61.9 \%$ of the teachers are strongly motivated by this intrinsic factor. This result partly supports Maslow's view that individuals are likely to prioritize personal autonomy and independence as important stimulating factor. These findings on responsibility are supported by Ushioda (cited by
Praver and Oga-Baldwin, 2008) that the more responsibility within the work an individual has, the more likely that the individual will be eager and prepared to work effectively.

Teachers still remain motivated by the other factor, "salary" or financial compensation, in which $50 \%$ of the teachers reported as being strongly motivated and $45,2 \%$ reported as being motivated. This finding appears to resonate reports from previously conducted studies that extrinsic factor of motivation is generally perceived as important. For instance, Andy Hockley (2006) surveyed 105 teachers about their motivation at work and found that salary was one of the most commonly identified factors for teacher motivation. 
It is also found that the teachers are motivated intrinsically with "sense of achievement" in their professional job. Generally, every teacher wants to feel a sense of accomplishment, a feeling proud of the work they have done. The result supports the reviewed literature that people naturally become more engaged in their work, and more motivated to maintain and improve their good work when they feel a sense of achievement (Acquah, 2017).

"Potential for professional growth" and "job security and stability" ranked fourth and fifth respectively in the study. According to these results, it seems that teachers could be more motivated if they can learn professionally and feel safe and secure, both at present and into the future. This result is also in line with some past research (Wang et al., 2015) reporting that employees ranked job security as one important contributing factor to job satisfaction.

It is interesting to notice that of the five most important factors of motivation in this study, the esteem (responsibility) comes first, followed by physiological needs (salary), and back to self-actualization (sense of achievement and potential growth) and then back to safety (job security and stability). The findings do not reflect the hierarchy ranking, suggested by Maslow that the motivational strength of an unfulfilled higher-level need depends on the fulfillment of a lower-level need (Eren, 1993). It appears that the findings of this study cannot be evaluated according to Maslow's theory alone.

The group of factors in the middle ranking from $6^{\text {th }}$ to $12^{\text {th }}$, namely, "working conditions", interpersonal relationships with students", "status", "recognition", "potential for advancement", "interpersonal relationships with administrators", and "the center's policies" mostly are extrinsic factors. Working conditions such as classrooms and facilities are physiological need, motivating foreign language teachers as in the 21th century, teachers should be able to be conversant with technology, updated teaching and learning materials, and modern equipment for teaching. The result is consistent with the report by Leithwood (2006) revealing the interdependence of teachers' performance and working conditions. The report emphasizes that the working conditions that enable teachers to do their best will also provide insights about how to support teachers' efforts to further develop their abilities and motivations.

It also appears that interpersonal relationships with students and with administrators moderately motivate foreign language teachers in this study as
$38.1 \%$ and $28.6 \%$ of the teachers respectively have reported to be strongly motivated when they establish good relationships with their students and with the Center's superiors. The result supports existing literature that good interpersonal relations contribute to the school's effectiveness by creating a healthy and friendly school climate and a learning environment which can stimulate the teachers' motivation and satisfaction (Koula, 2015).

Status and recognition are in middle ranking with mean values of 4.21 and 4.17 , respectively. As teaching is a nation-building profession, the status of teaching is a good motivator for many teachers at this Center with approximately $35.7 \%$ of teachers reporting strongly motivated. The result supports the past research of Yuce et al. (2013). Regarding the factor of recognition, the result in this study is in line with the reviewed literature that teachers receiving recognition for their teaching have praised recognition programs as providing motivation for them to continue high-level instruction (Andrews, 2011).

With the last five motivators, namely "work itself", "interpersonal relationships with colleagues", "teacher evaluation", "supervision by supervisors", and "factors in personal life", the "work itself" is an intrinsic factor and is positively related to teachers' motivation as theorized by Hertzberg et al. (1959, cited in Abdulrahman and Hui, 2018). The result supports the study by Lam et al. (2001) reflecting that the work itself plays a key role in employee job satisfaction, although the level of motivation is not very high in this study. The level of motivation of the two motivators of "teacher evaluation" and "supervision by supervisors" are not high with the mean values of 4.00 and 3.95, respectively. It is predictable when teachers tend to be less motivated with these work-related pressure factors. This could be due to the reason that the teachers may feel a high level of stress with teaching evaluations and dealing with the superiors at their workplace. The results are relatively consistent with the previous research (Ali and Al-Adawi, 2013), indicating that positive or negative feedbacks on school practicum for a group of EFL teachers in Oman can influence their performance and satisfaction.

The last factor with the lowest mean value, 3.91 reflects effects of teaching job on teacher's personal lives. Although the teachers tend to be highly motivated with their professional status of teaching, they appear to be less motivated with the influence of 
professional life on their personal life. The explanation can be that in this study the teachers appear not to emphasize the interactions between their professional lives and their personal lives. The result partly supports the findings of a study by Durham-Barnes (2011) indicating that teachers' professional lives slightly influenced their personal lives.

\subsection{Interview}

Through focus group discussions, the participants positively expressed views on motivators and the influence of motivation on teachers' performance. The results also confirmed that intrinsic motivators are more significant in ensuring quality in teachers' professional practice. It is interesting to note that salary was not the first priority of teachers' motivation, but most teachers indicated professional growth as their important motivator. Some typical responses are "development in my profession is the most important" and "salary is not my most important motivator but opportunities for professional growth are more valued."

Most participants expressed a significant influence of professional training and development on teachers' motivation. Most teachers in the interview shared the idea of "learning from workshops and training sessions is very practical." The findings of this study are partly in line with those of Walsh and Taylor (2007, cited in Jonathan, 2015) that training activities are correlated with productivity and retention.

Teachers also mentioned interacting with young learners and large size-class management as one of the main challenges in their teaching practice.

Young learners are not easy to concentrate for a long time, and to interact with them well, teachers should create a comfortable learning environment.

Classes of more than 20 young learners are usually challenging, and good communication is the key to manage the crowded class.

The result partly supports the findings in a study by Okeke and Mtyuda (2017), indicating important external factors such as large class sizes influencing teachers' motivation.

Findings from the group discussions also suggested that teacher's evaluation as the biggest source of dissatisfaction. Although most participants recognized the necessity of this activity, they generally complained about the high frequency of class visits and lack of supervisors' sufficient feedbacks for their improvement.
Getting feedback from class observation is very useful, but being observed is always an uneasy experience.

The frequency of class observation for teaching evaluation should not be too high.

Teaching evaluation should be informative and performance-based. This activity can be less stressful when two sides agree on evaluation criteria.

Concerning teachers' motivation and its influence on individual performance, most participants confirmed that when they perceived being highly motivated, they would be more positive in putting their very best for individual performance and the center's success. The results strongly support the similar findings by Jonathan (2015), showing that teachers placed great value on their motivation and work performance.

\section{CONCLUSION AND IMPLICATIONS}

\subsection{Conclusion}

This study has sought to identify important factors for teachers' motivation for quality teaching at a center for foreign languages. In light of the findings, it can be concluded that the teachers at this particular language center are motivated and strongly motivated. Intrinsic factors such as responsibility for work, sense of achievement and potential for professional growth together with extrinsic factors such as salary and job security are important motivators to enhance teachers' performance.

Motivating teachers is critical to their effectiveness for enhancing the quality of education. Increasing teachers' motivation can improve their teaching performance. Once teachers are highly motivated, they turn out to render quality services, increase their performance and commitments to their jobs and consequently help guarantee quality of education.

\subsection{Implications}

Based on the findings that do not fully reflect the hierarchy ranking as proposed by Maslow (1970, cited in Abdulrahman and Hui, 2018), it is implied that instead of prioritizing to improve salary or work incentives for teachers in an attempt to motivate teachers, the Center can instead invest in teachers' growth, training and development by sponsoring teachers to undertake professional development activities. Important increases in responsibility can be effective in motivating teachers; there should be opportunities for teachers for autonomy and variety, and for a sense of shared decision-making and 
achievement. Teachers also should benefit from feedback about the progress.

Teachers in this study have both intrinsic and extrinsic needs. Whether teachers are intrinsically or extrinsically motivated affect their performance and quality of education. The aim of the Center's management, therefore, should be to build on and enhance both intrinsic and extrinsic motivation for teachers to teach effectively. The Center's management should be aware of the supporting needs of teachers and methods of providing assistance in order to enhance their motivation.

To enhance the quality of education, the Center should be committed to ensuring that teachers are strongly motivated. The Center's management should recognize that different motivators are appropriate for different staff and that different staff will demonstrate different inherent levels of motivation in setting their own targets and striving towards them. Good management consists of recognizing and working with those individual differences.

\section{REFERENCES}

Abdulrahman, A. S. and Hui, X., 2018. Implication of motivation theories on teachers performance in the context of educational system in Tanzania. International Journal of Secondary Education. 6(3): 46-53.

Acquah, A., 2017. Implications of the achievement motivation theory for school management in Ghana: A literature review. Research on Humanities and Social Sciences. 7(5): 10-15.

Agatha, O. C., 2015. Teachers and quality assurance in education. International Journal of Humanities Social Sciences and Education. 2(4): 151-161.

Ali, H. I. H. and Al-adawi, H. A., 2013. Providing effective feedback to EFL student teachers. Higher Education Studies. 3(3): 21-35.

Andrews, H. A., 2011. Supporting quality teachers with recognition. Australian Journal of Teacher Education. 36(12): 59-70.

Ayeni, A. J., 2015. Teachers' motivation as strategy for sustenance of instructional task quality and standards in secondary schools in Ondo state, Nigeria. Journal of Education and Human Development. 4(4): 91101.

Bennell, P., and Akyeampong, K., 2007. Teacher motivation in Sub-Saharan Africa and South Asia. DFID Publications. 114 pages.

Claeys, L., 2011. Teacher motivation to teach and to remain teaching culturally and linguistically diverse students. Doctor of Philosophy in Education and $\mathrm{Hu}-$ man Development Bicultural-Bilingual Studies, The University of Texas at San Antonio, Texas, accessed
12 August 2019. Available from https://www.researchgate.net/profile/Lorena_Claeys/publication/279338701_Teacher_motiva-

tion_to_teach_and_to_remain_teaching_culturally_and_linguistically_diverse_students/links/583fc49608ae61f75dc79d21/Teachermotivation-to-teach-and-to-remain-teaching-culturally-and-linguistically-diverse-students.pdf

Durham-Barnes, J., 2011. The balancing act: The personal and professional challenges of urban teachers. PennGSE Perspectives on Urban Education. 9(1): 1-12.

Eren, E., 1993. Management and organization. 2nd ed. Istanbul: Beta Basim Yayim Dagitim.

Gokce, F., 2010. Assessment of teacher motivation. School Leadership and Management. 30(5): 487-499.

Hockley, A., 2006. What makes teachers tick? IATEFL Leadership \& Management SIG Newsletter. 37(1): 10-13.

Jonathan, N. C., 2015. Motivation and teachers' performance in selected public secondary schools in Ikenne local government area of Ogun State. British Journal of Psychology Research. 5(3): 40-50.

Komorowska, H., 2017. Quality assurance in teacher education. Glottodidactica. 44(1): 23-38.

Koula, V., 2015. The interpersonal relations between teachers and between principals and teachers: Factors in the all-around development of the students' personality. Humanities and Social Science Review. 4(1): 481-495.

Lam, T., Baum, T., and Pine, R., 2001. Study of managerial job satisfaction in Hong Kong's Chinese restaurants. International Journal of Contemporary Hospitality Management. 13(1): 35-42.

Leithwood, K., 2006. Teacher working conditions that matter: Evidence for change. Elementary Teachers' Federation of Ontario, Toronto, Ontario, 119 pages.

Mertler, C. A., 2001. Teacher motivation and job satisfaction in the New Millennium, accessed on 10 April 2019. Available from http://wps.ablongman.com/wps/media/objects/510/522780/forms/jobsatis.pdf.

Ofojebe, W. N. and Ezugoh, T. C., 2010. Teachers' motivation and its influence on quality assurance in the Nigerian educational system. African Research Review. 4(2): 398-417.

Okeke, C. I., and Mtyuda, P. N., 2017. Teacher job dissatisfaction: Implications for teacher sustainability and social transformation. Journal of Teacher Education for Sustainability. 19(1): 54-68.

Orupabo, F. T. and Nwankwoala, H. N., 2018. Teachers job motivation and quality education delivery in Mission Secondary Schools. International Journal of Scientific Research in Education. 11(3b): 577-612. For reference: http://www.ijsre.com/assets/vol.\%2C11(3b)-orupabo---nwankwoala.pdf 
Praver, M. and Oga-Baldwin, W., 2008. What motivates language teachers: Investigate work satisfaction and second language pedagogy. Polyglossia. 14(2): 1-8.

Rowley, J., 1996. Motivation and academic staff in higher education. Quality assurance in Education. 4(3): 11-16.

Sah, K. P., 2016. Factors affecting teacher motivation in language teaching and learning. Academic Voices: A Multidisciplinary Journal. 6(1): 1-4.

Snowman, J., Mcown, R., and Biehler, R., 2008. Psychology applied to teaching (12 ed.). USA: Wadsworth Publishing. 672 pages.

Velez, S., 2007. What is motivation?, accessed on 10 August 2019. Available from http://ezine articles.com/?What-Is-Motivation\&id=945902
Wang, H.-J., Lu, C.-q., and Siu, O., 2015. Job Insecurity and job performance: The moderating role of organizational justice and the mediating role of work engagement. The Journal of Applied Psychology. 100(4): 1249-1258.

World Bank, 1994. Higher Education: The lessons of experience (English), accessed on 31 July 2019. Available from http://documents.worldbank.org/curated/en/303461468328502540/Higher-educationthe-lessons-of-experience.

Yuce, K., Sahin, E. Y., Kocer, O., and Kana, F., 2013. Motivations for choosing teaching as a career: A perspective of pre-service teachers from a Turkish context. Asia Pacific Education Review. 14(3): 295-306. 